\title{
The Effect of Reward Practices on Employees' Motivation in Banking Industry: A Comparative Study of Selected Public and Private Commercial Banks in South Gondar Zone, Ethiopia
}

\author{
Tilahun Lakew Alebel Woretaw \\ Lecturer, Debre Tabor University, Debre Tabor, Ethiopia \\ Bihon Tsega \\ MBA Researcher, Debre Tabor University, Debre Tabor, Ethiopia
}

\begin{abstract}
Safe working environment is very important for any organization to create competitive employee in the world. The main objectives of this research was to assess the effect of reward practices on employees' motivation in selected Public and Private Banks /Commercial Bank of Ethiopia, Bank of Abyssinia and Abay Bank/ in South Gondar Zone. After intensive review of prior literature, we have selected payment, benefit, promotion working condition, recognition, and training opportunities as dimensions of reward. The study was done based on primary and secondary data sources. A self-administered questionnaire was designed to collect relevant information from the selected 203 respondents. Among this 200 questionnaire were returned and analyzed. Multistage sampling method was used and employees are selected from each stratum with a systematic sampling technique. The collected data was analyzed by SPSS version 20 using descriptive statistics and multiple regressions. Quantitative research approach and Explanatory research design was employed to show the cause and effect of independent and dependent variables. Based on the result of multiple linear regression variables like recognition and training have positive and significance effect on employee's motivation in Commercial bank of Ethiopia, and also payment and training variables have positive and significance effect on employee's motivation in private banks. On the other side promotion and recognition have been found insignificant in CBE and in Private Banks respectively than other variables in the model. Since the relation between rewards and motivation exist, the management of commercial bank of Ethiopia and Private Banks shall be follow better rewarding techniques to increase the performance of employees as well as achieving organizational objectives.
\end{abstract}

Keywords: Reward Practices, employee's motivation, Commercial Banks, South Gondar Zone.

DOI: $10.7176 /$ RJFA/11-1-05

Publication date: January $31^{\text {st }} 2020$

\section{Introduction}

According to Malik et al., (2011) reward system is a very important tool that all banks can use to sound employee's motivation in different ways. In other words, banks give rewards to employees; and reward system seeks not only to attract new employees to join the bank but also to keep existing employees and also motivate them to perform at high level (Mohemmed, 2011). Basically, all types of rewards motivate employees to perform well by attracting with well designed compensation package by banks. Dewhurst et al., (2010) described that there are other means to reward employees and they do not just focus on financial compensation (rewards).

Reward, of which can be in terms of monetary or non-monetary, is the key factor to attract or retain talents and to motivate employees to become good performers. Reward management in business organizations not only consists of financial rewards such as pay but they also consist of non-financial rewards such as employee recognition and employee training \& development (Armstrong and Murlis, 2004).

Employee motivation is a complex process (Armstrong, 2005) described that it depends on several factors. Like, individual needs and aspiration, expectation about the reward, equity and fairness (the felt fair principle) and other factor. Currently in Ethiopia there are 17 commercial banks, among these sixteen are private banks and one is public bank (CBE) (www.nbe.gov.et).

Commercial Bank of Ethiopia, Bank of Abyssinia and Abay Bank are among those Banks which have a better number of branches in South Gondar Zone than others. These Banks like other financial institutions are struggling to earn as large market share as possible, by attracting and retaining motivated employees for providing excellent banking service to its customers (Mohamedi, 2013). Having good products alone is not enough to attract more customers to join and transact with the bank unless skilled and motivated human resource is available. The data that has been collected from both public and private commercial banks reflects the employee's opinions towards reward practices; this provides important information for both sectors \& banks incentive planners. Therefore, this study was tried to show the effect of rewards on employee's motivation in selected public and private commercial banks. 
Objective of the study

General Objective

The Main Objective of the Study was to assess the Effect of Rewards on Employees Motivation in CBE and selected Private Banks (BoA \& Abay Bank).

\section{Specific Objectives}

1. To identify the perception of employees towards reward practices on employees' motivation in CBE and private banks.

2. To identify the effect of rewards on employee's motivation in CBE and Private Banks.

3. To examine similarity \& difference between $\mathrm{CBE}$ and private banks based on motivational factors.

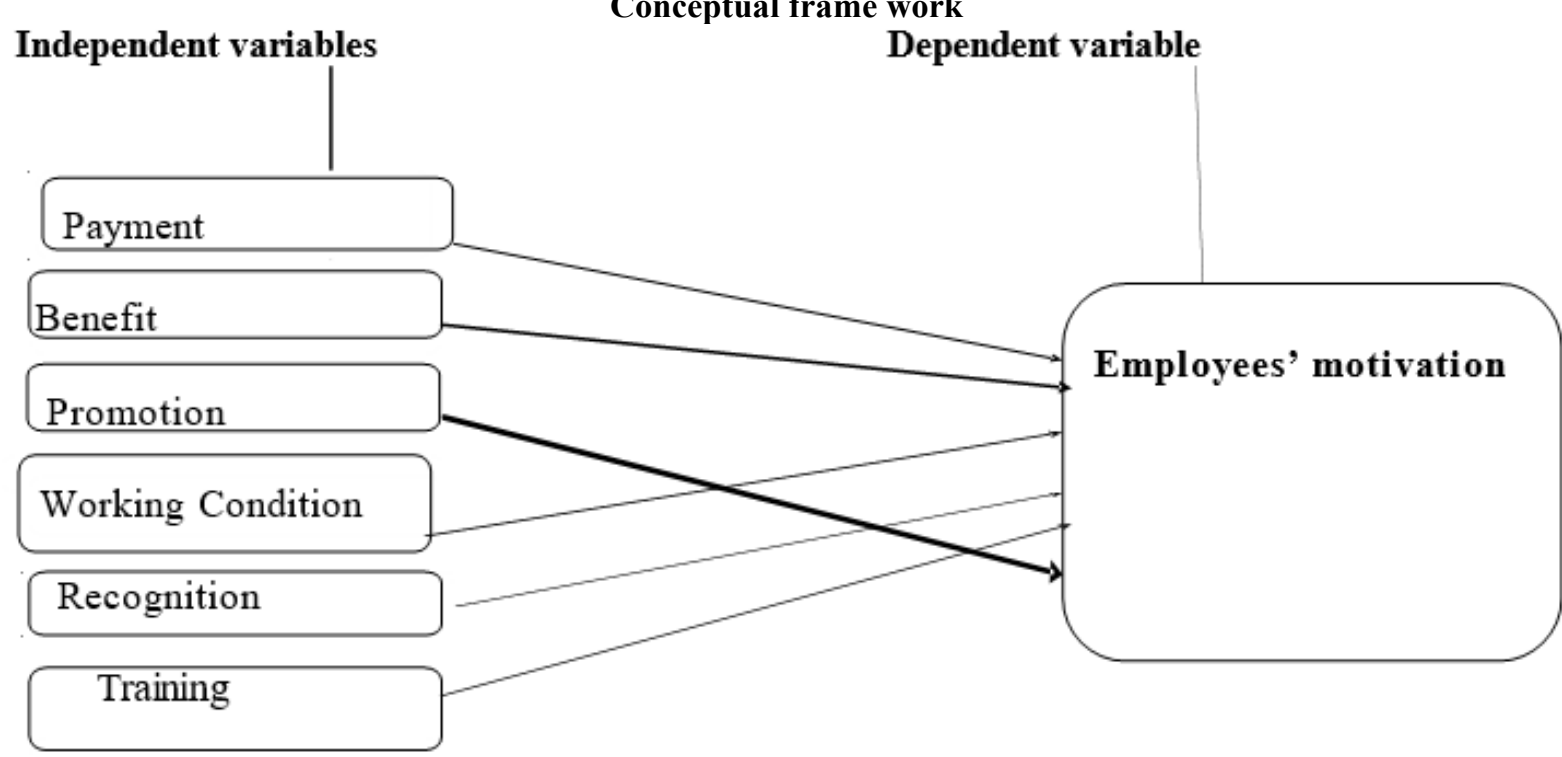

\section{RESEARCH METHODOLOGY}

This chapter presents the research methodology that was used to conduct this study thus, it focused on the following: research design, population and sampling techniques, data collection methods, research procedures, and data analysis methods.

\section{Description of the study area}

The study was conducted in South Gondar Zone, Which is found in Amhara Regional state, Ethiopia, by considering Public Commercial Bank (CBE) and private Banks of Bank of Abyssinia (BoA) and Abay Bank which have more number of branches \& Employees than other banks in this zone. South Gondar Zone has 13 woredas such as Farta, Fogera, Estie, Simada, Tachgaint, Laygaint, Dera, Libokemkem, Ebnat, Andabet, Sediemuja, Gunabegemidir, Meketwa and 5 Towns Administration namely Debre Tabor (the town where zone administrator placed), Nefasmewucha, addiszemen, woreta and MekaneEyesus. There are 9 commercial banks (CBE and 8 private banks) in this Zone. However the three (CBE, BoA and Abay) banks have more branches than others.

Commercial bank of Ethiopia (CBE) is the leading bank in Ethiopia established in 1942; pioneer to introduce modern banking in the country. $\mathrm{CBE}$ has more than 1240 branches stretched across the country (www.combanketh.et).

Bank of Abyssinia (BoA) which was established in 1996 and 338 branches in the country of Ethiopia (www.bankofabyssinia.com). Abay Bank was officially established on July 14, 2010, fulfilling all the necessary requirements of the National Bank of Ethiopia to set up a bank and started fully fledged banking operations on November 3, 2010 by registering 157.8 million $\mathrm{Br}$ in paid up capital, mobilized from 823 founding shareholders. (www.abaybank.com).

\section{Research Design}

The research designs for this study is explanatory research design to explain, understand and predict the cause and effect relationship between variables that is reward dimensions (independent variables) and employee's motivation (dependent variable).

\section{Research Approach}

Quantitative research involves studies that make use of statistical analyses to obtain their findings. Key features 
include formal and systematic measurement and the use of statistics (Marczyk et al., 2005). Therefore, for this research Quantitative research approach is used, because it used structural questionnaire data collection method and statically data analysis techniques.

\section{Target Population.}

According to 2018/19 annual report of the banks, there are 305 employees in CBE, 47 employees in BoA and 62 employees from Abay Bank in south Gondar Zone. Therefore, the total population of the study was 414 and sample survey used to undertake the study.

$$
n=\frac{N}{1+N^{*}(e)^{2}}
$$

Where; $\mathbf{n}=$ sample size

$$
\mathbf{N}=\text { Total population }
$$

$\mathbf{e}=$ Error tolerance.

The margin error for this study is $5 \%$, and using this information, the sample size is equal to:

$$
n=\frac{414}{1+414(0.05)^{2}}=203
$$

So from the target population of 414 employees the researcher selected 203 employees in 29 branches of three banks as sample to distribute the questionnaires. Since the number of branches in each Bank is not the same, the number of samples for each Bank is taken based on their proportion of number of branches.

\section{Sampling Techniques}

The researcher was used multistage sampling; First Convenience sampling was used to select the study area which was south Gondar zone. Because convenience sampling is the most easily accessible members are chosen as subjects and it is quick, convenient and less expensive (Kothari).

Secondly CBE, BoA and Abay bank were chosen purposively based on number of branches opened and the number of employees working at these branches. Thirdly un proportional stratified sampling was employed based on the number of branches that the banks have. According to the method which proposed by (Bowley, 1926), the sample size will be drawn from each Bank as follows Sample size from each bank= number of branches for each bank X Total sample size of total branches of the bank

Sample size determination

\begin{tabular}{|l|l|l|l|}
\hline Bank & Total Number of employees in each bank & $\begin{array}{l}\text { Number of branches in the Sample size } \\
\text { Bank }\end{array}$ & Sam \\
\hline CBE & 305 & 17 & 119 \\
\hline BoA & 47 & 5 & 35 \\
\hline Abay bank & 62 & 7 & 49 \\
\hline Total & 414 & 29 & 203 \\
\hline
\end{tabular}

Source: researcher's own compilation of Survey data 2019

Finally, systematic sampling (every $\mathrm{n}^{\text {th }}$ element in the population is chosen staring from random point in the sampling frame) is used to select the sample respondents from each bank except out sourced employees.

\section{Sources of Data}

The researcher was used both primary and secondary data in its construction. Primary data were collected by distributing structured questionnaire for the employees of CBE, BoA and Abay Bank. On the other hand the secondary data were collected from sources like prior researches, articles, books, interne and different manuals and documents of the bank. The researcher collected secondary data for complementing the data obtained from the primary source.

\section{Data Gathering Tools}

The main data collection instrument utilized in this study was questionnaire.

According to Leary (2004), Questionnaire is usually inexpensive, easy to administer a large number of employees and less time consuming and normally gets more consistent and reliable results than other instruments. The questionnaires employed in this research contains Demographic characteristics of respondents and close-ended by which the respondents are asked to indicate their level of agreement using a five likert rating scale measurement where: Strongly disagree $(\mathrm{SD})=1$; disagree $(\mathrm{D})=2$; $\operatorname{Neutral}(\mathrm{N})=3$, agree $(A)=4$; and strongly agree $(\mathrm{SA})=5$.

Data Analysis and tools

To fulfill the objective of the research, the data analysis was done. The data that were collected from the 
primary survey are summarized, compiled, edited, and coded. Descriptive and inferential statistics were employed for the data analysis process by using computer software called Statistical Package for social science (SPSS) version 20 .

\section{Model of the study}

The model employed was multiple linear regressions. Multiple linear regression analysis is used to explore the relationship between one dependant variable and a number of independent variables or predictors (Pallant, 2005). $Y=\alpha+\beta_{1} P+\beta_{2} B+\beta_{3} P r+\beta_{4} W+\beta_{5} R+\beta_{6} T+U i$

Where; $\mathrm{Y}=$ employee's Motivation .

$\alpha=$ the constant, or $\mathrm{Y}$ intercept

$\beta \mathrm{i}=$ The coefficient of the independent variables

$\mathrm{P}=$ Payment

$\mathrm{B}=$ Benefit

$\mathrm{Pr}=$ Promotion

$\mathrm{W}=$ working condition

$\mathrm{R}=$ Recognition

$\mathrm{T}=$ Training

$\mathrm{i}=$ the error term

The regression analysis was performed based on data collected from employees of each bank. The researcher demonstrates the relationship between rewards on employee's motivation and comparison of CBE and private banks (BoA and Abay Bank) .

\section{Reliability Test}

Reliability test is used to assess consistency in measurement items (Cerri, 2012).

Cranach's alpha is used to measure the internal consistency of the measurement items. Cranach's alpha is a tool for assessing reliability scale which normally ranges between 0 and 1.Internal consistency reliability is a measure of consistency between different items of the same construct. If a multiple item construct measure is administered to respondents, the extent to which respondents rate those items in a similar manner is a reflection of internal consistency. According to George and Mallery (2003) a Cranach's alpha coefficient greater than 0.9 implies excellent, greater than 0.8 is good, greater than 0.7 is acceptable, greater than 0.6 is questionable, greater than 0.5 is poor, and less than 0.5 is unacceptable.

\section{DATA PRESENTATION ANALYSIS AND INTERPRETATION}

This chapter presents a discussion of the final results and the process through which the Results are obtained. In addition to this, background information of respondents is presented. Finally, the statistical methods of analysis were discussed, which include a descriptive analysis, a correlation analysis, and a regression analysis. Response rate in each bank

\begin{tabular}{|c|c|c|c|}
\hline Bank & Sample size & Response & Percentage \\
\hline CBE & 119 & 116 & $97.5 \%$ \\
\hline BoA & 35 & 35 & $100 \%$ \\
\hline Abay Bank & 49 & 49 & $100 \%$ \\
\hline Total & 203 & 200 & $98.5 \%$ \\
\hline
\end{tabular}

Source: own Survey 2019

As shown in the table above a total of 203(100\%) questionnaires are distributed to systematically selected employees of $\mathrm{CBE}$ and private banks (BoA and Abay Bank) branches found in South Gondar Zone. Out of these, 3 questionnaires were discarded from the analysis because of incomplete completions of CBE employees. The rest 200 questionnaires (98.5\%) are fully completed properly and used in the analysis. Accordingly, the analysis of this study was based on the number of questionnaires collected.

\section{Demographic Characteristics of Respondents}

The demographic information of respondent gathered for this study was gender, age, education level, years of service and Salary. 
Gender Composition of Respondents in each bank

\begin{tabular}{|l|l|l|l|l|l|l|}
\hline \multirow{2}{*}{$\begin{array}{l}\text { Name of the } \\
\text { bank }\end{array}$} & Male & Frequency & $\%$ & Frequency & $\%$ & Total \\
\hline CBE & 87 & 75 & 29 & 25 & Frequency & $\%$ \\
\hline BOA & 26 & 74.3 & 9 & 25.7 & 116 & 100 \\
\hline Abay Bank & 30 & 61.2 & 19 & 38.8 & 49 & 100 \\
\hline Total & 143 & 71.5 & 57 & 28.5 & 200 & 100 \\
\hline
\end{tabular}

Source: own Survey 2019

It presents the sex composition of the respondents. Of the total 200 respondents $143(71.5 \%)$ are male and the remaining 57(28.5\%) are female. Of the total 143 male respondents, $87(75 \%)$ are from Public Sector Bank/CBE/, 26 (74.3\%) are from BoA and 30(61.2) are from Abay Bank. Whereas the female respondents are $29(25 \%), 9(25.7)$ and $19(38.8 \%)$ are from CBE, BoA and Abay bank respectively. It also shows total gender of the respondent which is $71.5 \%$ are males and $28.5 \%$ are females, which indicate, the majority of the respondents are male.

\section{Age Composition of Respondents}

The study needed to know the age distribution of respondents to help categorize employees and assess whether ages of employees are taken into consideration in selection of employees in each banks.

Age Distribution of Respondents

\begin{tabular}{|l|l|l|l|l|l|l|l|l|}
\hline \multirow{2}{*}{$\begin{array}{l}\text { Name of public and } \\
\text { private bank }\end{array}$} & \multicolumn{2}{|l|}{ CBE } & BOA & Abay Bank & \multicolumn{2}{l|}{ Total } \\
\cline { 2 - 10 } & Frequency & $\%$ & Frequency & $\%$ & Frequency & $\%$ & Frequency & $\%$ \\
\hline Under 25 & 25 & 21.6 & 5 & 14.3 & 13 & 26.5 & 43 & 21.5 \\
\hline 36to35 to 45 & 89 & 76.7 & 22 & 62.9 & 26 & 53.1 & 137 & 67 \\
\hline Above 45 & 2 & 1.7 & 7 & 20 & 8 & 16.3 & 17 & 8.5 \\
\hline Total & & & 1 & 2.8 & 2 & 4.1 & 6 & 3 \\
\hline
\end{tabular}

Source: own Survey 2019

As indicated from the above Table classification of respondents by age, $67 \%$ of the respondents fall under the categories of 25 up to 35 . This shows that majority of the respondents are young applicants and most of whom are recent graduates.

Educational Levels of Respondents

\begin{tabular}{|l|l|l|l|l|l|l|l|l|}
\hline \multirow{2}{*}{$\begin{array}{l}\text { Name of public } \\
\text { and private bank }\end{array}$} & \multicolumn{1}{l|}{ BOA } & A & \multicolumn{2}{l|}{ Abay Bank } & \multicolumn{2}{l|}{ Total } \\
\cline { 2 - 10 } & Frequency & $\%$ & Frequency & $\%$ & Frequency & $\%$ & Frequency & $\%$ \\
\hline Diploma & 96 & 82.8 & 2 & 5.7 & 7 & 14.2 & 9 & 4.5 \\
\hline Degree & 20 & 17.2 & 31 & 88.6 & 38 & 77.6 & 165 & 82.5 \\
\hline Masters & & & 2 & 5.7 & 4 & 8.2 & 26 & 13 \\
\hline Other & & & & & & & & \\
\hline Total & 116 & 100 & 35 & 100 & 49 & 100 & 200 & 100 \\
\hline
\end{tabular}

Source: own Survey 2019

The above table presents the education status of the respondents. About 96 percent of the respondents are having either a degree level education or more in both banks. In the case of CBE, out of the total respondents $96(82.8 \%)$ are qualified with first degree education and $20(17.2 \%)$ have Maters degree. BoA 2(5.7\%) respondents have diplomas, 31( 88.6\%) have first degree and 2(5.7\%) have masters Degree. in the case of Abay Bank 7 (14.2\%) have diploma and the remaining 38(77.6) and 4(8.2) are degree and masters qualified respectively. The above data can serve as a preliminary indicator for the general training needs that each bank is supposed to provide to employees in the deferent levels of qualifications mentioned above.

\section{Work Experience of the Respondents}

Respondents were asked to indicate their work experience in their carrier. Accordingly the results are presented in the table below. 


\begin{tabular}{|l|l|l|l|l|l|l|l|l|}
\hline \multirow{2}{*}{$\begin{array}{l}\text { Name of public } \\
\text { and private bank }\end{array}$} & \multicolumn{2}{|l|}{ CBE } & \multicolumn{2}{l|}{ BOA } & \multicolumn{2}{l|}{ Abay Bank } & \multicolumn{2}{l|}{ Total } \\
\cline { 2 - 10 } & Frequency & $\%$ & Frequency & $\%$ & Frequency & $\%$ & Frequency & $\%$ \\
\hline Below 3 years & 10 & 8.6 & 9 & 25.7 & 14 & 28.6 & 33 & 16.5 \\
\hline $3-5$ & 58 & 50 & 11 & 31.4 & 17 & 34.7 & 86 & 43 \\
\hline $6-10$ & 43 & 37.1 & 15 & 42.9 & 18 & 36.7 & 76 & 38 \\
\hline Above 10 & 5 & 4.3 & & & & & 5 & 2.5 \\
\hline Total & 116 & 100 & 35 & 100 & 49 & 100 & 200 & 100 \\
\hline
\end{tabular}

Source: own Survey 2019

As can be seen in the above table the majority of respondents in all banks which is $43 \%$ have a work experience between 3 and 5, 16.5\% have a work experience three and below years. Respondents which have work experience of 6-10 years are 38\%. The remaining respondents $(2.5 \%)$ have above 10 years work experience. In the case of $\mathrm{CBE}$, the majority of respondents $(58.6 \%)$ have a total of work experience in banks between $1-5$ years, and $37.1 \%$ of the respondents are having a total of work experience that ranges from 6 to 10 . On the other hand, regarding work experience in banks of respondents of private banks BoA and Abay bank, 57.1\% and $63.3 \%$ are respectively have a total work experience in banks that ranges from 1-5 years, and also BoA respondents of $42.9 \%$ and Abay bank respondents of $36.7 \%$ have experiences within a range of 6 to 10 years. Only CBE of 5(4.3\%) respondents have a work experience of above 10 Years. From this we can conclude that most employees in banks are with less than five year experience.

Gross Monthly Salary of Respondents

\begin{tabular}{|l|l|l|l|l|l|l|l|l|}
\hline \multirow{2}{*}{$\begin{array}{l}\text { Name of public } \\
\text { and private bank }\end{array}$} & \multicolumn{2}{|l|}{ BOA } & \multicolumn{2}{l|}{ Abay Bank } & \multicolumn{2}{l|}{ Total } \\
\hline & Frequency & $\%$ & Frequency & $\%$ & Frequency & $\%$ & Frequency & $\%$ \\
\hline $2000-4000$ & 10 & 8.6 & & & & & 10 & 5 \\
\hline $4001-6000$ & 53 & 45.7 & 1 & 2.9 & 5 & 10.2 & 59 & 29.5 \\
\hline $6001-10000$ & 32 & 27.6 & 12 & 34.3 & 25 & 51 & 69 & 34.5 \\
\hline $10001-15000$ & 18 & 15.5 & 18 & 51.4 & 14 & 28.6 & 50 & 25 \\
\hline $15001-25000$ & 3 & 2.6 & 3 & 8.6 & 5 & 10.2 & 11 & 5.5 \\
\hline Above 25000 & & & 1 & 2.8 & & & 1 & 0.5 \\
\hline Total & 116 & 100 & 35 & 10 & 49 & 100 & 2 & 100 \\
\hline
\end{tabular}

surce: own Survey 2019

From the above table we can observe that in CBE the majority of the respondents are earning 4001- 6000 birr per month which accounts for $45.7 \%$ of the sample. The second largest respondents for CBE are between $6001-10000$ birr salary groups which is $27.6 \%$ of the sample. The rest $8.6 \%$ of the respondent salary are $2000-4000$ birr, $15.5 \%$ of respondents are between $10001-15000$ birr monthly salary and only $3(2.6 \%)$ is earning a salary of 15001-25000 birr. On the other hand in the case of private bank, the majority of the respondents in BoA 51.4 are earning 10001- 15000 birr per month and in Abay bank 51\% of respondents are between 6001-10000 birr monthly salary. This implies that the private banks respondents have better monthly salary than CBE. And also BoA pays better salary than Abay bank. From the figure 4.5 we can observe that the majority banks ${ }^{e e}$ respondents are earning 6001-10000 monthly salary which accounts $34.5 \%$.

\section{Descriptive Analysis}

The arithmetic means and standard deviations of independent and dependent variables 


\begin{tabular}{|c|c|c|c|c|}
\hline \multicolumn{2}{|c|}{ Name of the bank } & \multirow{2}{*}{$\begin{array}{l}\text { Mean } \\
4.0819\end{array}$} & \multirow{2}{*}{$\begin{array}{l}\text { Std. } \\
.44694\end{array}$} & \multirow{2}{*}{$\frac{\mathbf{N}}{116}$} \\
\hline $\mathrm{CBE}$ & Employee Motivation & & & \\
\hline & Payment & 2.1897 & .89359 & 116 \\
\hline & Benefit & 3.4483 & .90741 & 116 \\
\hline & Promotion & 2.3879 & .90190 & 116 \\
\hline & Working Condition & 3.5086 & .97353 & 116 \\
\hline & Recognition & 3.0862 & .97418 & 116 \\
\hline & Training & 3.1638 & .99515 & 116 \\
\hline \multirow[t]{7}{*}{$\mathrm{BoA}$} & Employee Motivation & 4.1857 & .43868 & 35 \\
\hline & Payment & 3.8000 & .99410 & 35 \\
\hline & Benefit & 3.2571 & .98048 & 35 \\
\hline & Promotion & 2.8571 & 1.14128 & 35 \\
\hline & Working Condition & 4.3429 & .59125 & 35 \\
\hline & Recognition & 3.2000 & 1.02326 & 35 \\
\hline & Training & 2.6571 & 1.32716 & 35 \\
\hline \multirow{7}{*}{$\begin{array}{l}\text { Abay } \\
\text { Bank }\end{array}$} & Employee Motivation & 4.1633 & .31271 & 49 \\
\hline & Payment & 4.3061 & .46566 & 49 \\
\hline & Benefit & 3.9592 & .93450 & 49 \\
\hline & Promotion & 3.9184 & .99659 & 49 \\
\hline & Working Condition & 3.8367 & .77317 & 49 \\
\hline & Recognition & 4.0408 & .61098 & 49 \\
\hline & Training & 3.8776 & .59974 & 49 \\
\hline
\end{tabular}

Descriptive statistics in the form of arithmetic means and standard deviations for the independent variables and dependent variable for the respondents are computed and presented in Table above with respect to the dimensions of reward practices assessed by the work motivation and satisfaction questionnaire. According to the data presented in the above Table the mean scores for benefit (3.44), working condition (3.50), recognition (3.08) and Training (3.16) are above 3 in CBE. Since 3 is the mid-scale, it can be concluded that employees in CBE are satisfied by these variables. The mean score of payment and promotion variables are below 3 (2.18 and 2.38) respectively, indicating that employees in CBE do not see the chance for promotion as satisfying and demotivated for what they earned from the bank.

In BoA, mean scores of payment and promotion are 3.80 and 2.85 respectively indicating that employees in BoA satisfied with the amount of financial compensation that they get from the bank however not enjoy with the chance for promotion to the higher managerial hierarchy since mean score of the former is greater and the latter is less than the mid-scale. On the other hand the mean score of benefit (3.25), working condition (4.34) and recognition (3.20), training (4.30) are above 3, it can be conclude employees of BoA are satisfied by these variables, and unsatisfied by training opportunity which is a mean score of (2.65).

In the same way, the mean scores of payment (4.30), promotion (3.91), benefit (3.95), working condition (3.83), Recognition (4.04) and training (3.87) all are more than 3 and indicating that employees of Abay Bank satisfied with these variables. To this end, one can conclude that employees in CBE and $\mathrm{BoA}$ are not satisfied by the promotion practices of the bank. In addition to promotion employees in CBE have expressed their dissatisfaction in the amount of financial compensation they received from their employers. Meanwhile, employees in BoA have further expressed their dissatisfaction to the chance for being trained for better performance to the bank. The response of the respondents for that dependent variable of employee's motivation shows somewhat above average. This implies that the employees of CBE, BoA and Abay banks are motivated.

\section{Ranking Order of rewards by respondents}

The Respondents perception on reward practices that influence employees ${ }^{\text {ee }}$ motivation, from 1 st to $6^{\text {th }}$. Rank of rewards by respondents of CBE 


\begin{tabular}{|l|r|r|r|r|}
\hline $\begin{array}{l}\text { Reward } \\
\text { Practices }\end{array}$ & Frequency & Percent & $\begin{array}{c}\text { Valid } \\
\text { Percent }\end{array}$ & $\begin{array}{c}\text { Cumulative } \\
\text { Percent }\end{array}$ \\
\hline Payment & 36 & 31.0 & 31.0 & 31.0 \\
Benefit & 19 & 16.4 & 16.4 & 47.4 \\
Promotion & 22 & 19.0 & 19.0 & 66.4 \\
Recognition & 4 & 3.4 & 3.4 & 69.8 \\
Working & 29 & 25.0 & 25.0 & 94.8 \\
Condition & 6 & 5.2 & 5.2 & 100.0 \\
Training & 116 & 100.0 & 100.0 & \\
Total & & & \\
\hline
\end{tabular}

Source: own Survey 2019

The above Table shows that, out of total 116 respondents in CBE $31 \%$ of respondent's choice rank number 1 is Payment, 25\% respondents" choice working condition as 2 nd place, $19 \%$ respondents" choice promotion as 3rd place. $16.4 \%, 5.2 \%$ and $3.4 \%$ of the respondents choice is benefit, training and recognition as $4^{\text {th }}, 5^{\text {th }}$ and $6^{\text {th }}$ place respectively.

Therefore as the perception of employees we can infer that, payment is the highest influential factor for employee's motivation followed by working condition and promotion respectively in CBE, but according to respondents" choice of $\mathrm{CBE}$, training and recognition have the least motivational factors respectively.

Rank of rewards by respondents of BoA

\begin{tabular}{|l|r|r|r|r|}
\hline $\begin{array}{l}\text { Reward } \\
\text { Practices }\end{array}$ & Frequency & Percent & \multicolumn{1}{|c|}{$\begin{array}{c}\text { Valid } \\
\text { Percent }\end{array}$} & $\begin{array}{c}\text { Cumulative } \\
\text { Percent }\end{array}$ \\
\hline Payment & 11 & 31.4 & 31.4 & 31.4 \\
Benefit & 13 & 37.1 & 37.1 & 68.6 \\
Promotion & 5 & 14.3 & 14.3 & 82.9 \\
Recognition & 1 & 2.9 & 2.9 & 85.7 \\
Working & 5 & 14.3 & 14.3 & 100.0 \\
Condition & 35 & 100.0 & 100.0 & \\
Total & & & \\
\hline
\end{tabular}

Source: own Survey 2019

The above Table shows that, out of total 35 respondents in BoA $37.1 \%$ of respondents choice rank number 1 is benefit, $31.4 \%$ respondents" choice payment as 2 nd place, $14.3 \%$ respondent's choice promotion and working condition equally as 3rd place. $2.9 \%$ respondents choose recognition and no choice for training. Therefore we can infer that, benefit and payment are the highest influential factor, but training and recognition have the least motivational factors for employees of BoA.

Rank of rewards by respondents of Abay Bank

\begin{tabular}{|l|r|r|r|r|}
\hline $\begin{array}{l}\text { Reward } \\
\text { Practices }\end{array}$ & Frequency & Percent & $\begin{array}{c}\text { Valid } \\
\text { Percent }\end{array}$ & $\begin{array}{c}\text { Cumulative } \\
\text { Percent }\end{array}$ \\
\hline Payment & 20 & 40.8 & 40.8 & 40.8 \\
Benefit & 14 & 28.6 & 28.6 & 69.4 \\
Promotion & 2 & 4.1 & 4.1 & 73.5 \\
Recognition & 4 & 8.2 & 8.2 & 81.6 \\
Working & 3 & 6.1 & 6.1 & 87.8 \\
Condition & 6 & 12.2 & 12.2 & 100.0 \\
Training & 49 & 100.0 & 100.0 & \\
Total & & & & \\
\hline
\end{tabular}

Source: own Survey 2019

The above Table shows that, out of total 49 respondents in Abay bank $40.8 \%$ of respondent's choice rank number 1 is payment, $28.6 \%$ respondent's choice Benefit as 2 nd place, $12.2 \%$ respondents choice training as 3rd place. Therefore we can infer that, payment and benefit are the highest influential factor, but promotion and working condition have the least motivational factors for employees of Abay bank. Therefore from the above we can conclude that the perception of employees is different according to the organization environment and the reward practices in the organization.

The rank of rewards in CBE, BoA and Abay Bank as a whole by respondents 


\begin{tabular}{|l|r|r|r|r|}
\hline & Frequency & Percent & $\begin{array}{c}\text { Valid } \\
\text { Percent }\end{array}$ & $\begin{array}{c}\text { Cumulative } \\
\text { Percent }\end{array}$ \\
\hline Payment & 67 & 33.5 & 33.5 & 33.5 \\
Benefit & 46 & 23.0 & 23.0 & 56.5 \\
Promotion & 29 & 14.5 & 14.5 & 71.0 \\
Recognition & 9 & 4.5 & 4.5 & 75.5 \\
Working & 37 & 18.5 & 18.5 & 94.0 \\
Condition & 12 & 6.0 & 6.0 & 100.0 \\
Training & 200 & 100.0 & 100.0 & \\
Total & & & \\
\hline
\end{tabular}

Source: own Survey 2019

From the above table it is possible to say that, out of total respondents (200) $33.5 \%$ of respondent choice rank number 1 is Payment, 23\% respondent's choice benefit and $18.5 \%$ respondents choice is working condition. About $14.5 \%, 6 \%$ and $4.5 \%$ respondent choice is promotion, training as $4^{\text {th }}, 5^{\text {th }}$ and $6^{\text {th }}$ place respectively. Therefore we can infer that, payment is the highest influential factor for employee motivation followed by Benefit, working condition and promotion, respectively, but according to respondents" choice training and recognition have the least motivational factors respectively.

\section{Correlation}

Correlation analysis is applied to test the "interdependency" of the variables. It shows the direction and degree of the strength of the relationship among the variables. The Pearson's Product Movement Correlation Coefficient ( $\mathrm{r}$ ) is computed to determine the relationships between explanatory variables and employee's motivation. Correlation analysis is useful way of exploiting relation (association) among variables. The value of the coefficient (r) ranges from -1 up to +1 . The value of coefficient of correlation (r) indicates both the strength and direction of the relationship. For values of $\mathrm{r}$ between +1 and 0 or between 0 and -1 , different scholars have proposed different interpretation with slight difference. For this study decision rule given by Bartz (1999) id used to describe the strength of association among the variables as follows.

Interpretation of $\underline{\mathbf{r}}$ Value

\begin{tabular}{|l|l|}
\hline Value of $\mathbf{r}$ & Description \\
\hline 0.80 or higher & Very high \\
\hline 0.6 to 0.8 & Strong \\
\hline 0.4 to 0.6 & Moderate \\
\hline 0.2 to 0.4 & Low \\
\hline 0.2 or bwer & Very bw \\
\hline
\end{tabular}

Pearson Correlation Analysis for independent and dependent variables 


\begin{tabular}{|c|c|c|c|c|c|c|c|c|}
\hline & & | Payment| & Benefit & Promotion & $\begin{array}{l}\text { Working } \\
\text { Condition }\end{array}$ & Recognition & Training & $\begin{array}{l}\text { employee's } \\
\text { Motivation }\end{array}$ \\
\hline \multirow[t]{3}{*}{ Payment } & $\begin{array}{l}\text { Pearson } \\
\text { Correlation }\end{array}$ & 1 & $.391^{* *}$ & $.659^{* *}$ & $.421^{* *}$ & $.453^{* *}$ & $.336^{* *}$ & .112 \\
\hline & Sig. (2-tailed) & & .000 & .000 & .000 & .000 & .000 & .115 \\
\hline & $\mathrm{N}$ & 200 & 200 & 200 & 200 & 200 & 200 & 200 \\
\hline \multirow[t]{3}{*}{ Benefit } & $\begin{array}{l}\text { Pearson } \\
\text { Correlation }\end{array}$ & $.391^{* *}$ & 1 & $.399^{* 4}$ & .043 & $.342^{* *}$ & $.476^{* *}$ & $.190^{* *}$ \\
\hline & Sig. (2-tailed) & .000 & & .000 & .541 & .000 & .000 & .007 \\
\hline & $\mathrm{N}$ & 200 & 200 & 200 & 200 & 200 & 200 & 200 \\
\hline \multirow[t]{4}{*}{ Promotion } & Pearson & & & & & & & \\
\hline & Correlation & $.659^{* *}$ & $.399^{* *}$ & 1 & $.291^{* *}$ & $.599^{* *}$ & $.524^{* *}$ & .044 \\
\hline & Sig. (2-tailed) & 000 & .000 & & .000 & .000 & .000 & .537 \\
\hline & $\mathrm{N}$ & 200 & 200 & 200 & 200 & 200 & 200 & 200 \\
\hline Working & Pearson & & & & & & & \\
\hline \multirow[t]{3}{*}{ Condition } & Correlation & $.421^{* *}$ & .043 & $.291^{* *}$ & 1 & $.171^{*}$ & $.274^{* *}$ & -.074 \\
\hline & Sig. (2-tailed) & 000 & 541 & 000 & & 016 & 000 & 299 \\
\hline & $\mathrm{N}$ & & & & 200 & 200 & 200 & 200 \\
\hline \multirow[t]{3}{*}{ Recognition } & $\begin{array}{l}\text { Pearson } \\
\text { Correlation }\end{array}$ & $.453^{\circ *}$ & $.342^{* *}$ & $.599^{* *}$ & $.171^{\circ}$ & 1 & $.517^{*}$ & $.235^{* *}$ \\
\hline & Sig. (2-tailed) & .000 & .000 & .000 & .016 & & .000 & .001 \\
\hline & $\mathrm{N}$ & 200 & 200 & 200 & 200 & 200 & 200 & 200 \\
\hline \multirow[t]{3}{*}{ Training } & $\begin{array}{l}\text { Pearson } \\
\text { Correlation }\end{array}$ & $.336^{\circ *}$ & $.476^{* *}$ & $.524^{* *}$ & $.274^{* *}$ & $.517^{* *}$ & 1 & $.256^{* *}$ \\
\hline & Sig. (2-tailed) & .000 & .000 & .000 & .000 & .000 & & .000 \\
\hline & $\mathrm{N}$ & 200 & 200 & 200 & 200 & 200 & 200 & 200 \\
\hline \multirow[t]{3}{*}{$\begin{array}{l}\text { Employees } \\
\text { Motivation }\end{array}$} & $\begin{array}{l}\text { Pearson } \\
\text { Correlation }\end{array}$ & .112 & $.190^{* *}$ & .044 & -.074 & $.235^{* *}$ & $.256^{* *}$ & 1 \\
\hline & Sig. (2-tailed) & .115 & .007 & .537 & .299 & .001 & .000 & \\
\hline & $\mathrm{N}$ & 200 & 200 & 200 & 200 & 200 & 200 & 200 \\
\hline
\end{tabular}

**. Correlation is significant at the 0.01 level (2-tailed).

*. Correlation is significant at the 0.05 level (2-tailed).

Source: own Survey 2019

As can we see from the above table benefit relatedness to employeese motivation i.e. $(r=0.190, p<0.01)$ there exist a positive and statistically significant relationship in between. It can be also observed that, there exist a positive and statistically significant relationship between recognition and employees" motivation ( $\mathrm{r}=0.235$, $\mathrm{p}<0.01$ ), similarly there exist a positive and statistically significant relationship between training and employees ${ }^{\text {ee }}$ motivation $(\mathrm{r}=0.256, \mathrm{p}<0.01)$.

As shown in the table above it can be observed that, there is positive but not significant between payment $(\mathrm{r}=0.112, \mathrm{p}<0.01)$, and promotion $(\mathrm{r}=0.044, \mathrm{p}<0.01)$ with employee's motivation. There is a negative relationship observed between working condition and employee's motivation.

Correlations and Multicollinearity

To ensure that the regression results are reliable and unbiased, the assumptions underlying a regression analysis 
are examined. Hence, before presenting the regression models, it should be inspected for none existence of excessive correlations among the independent variables in the model. The correlation matrix in conjunction with colinearity statistics can be scanned as a preliminary look for multicolinearity in this case. To avoid multicolinearity in the research variables, there should be no substantial correlations $(\mathrm{R}>0.9)$, tolerance value below 0.1 and variable inflation factor over 5 (Marczyk, 2005).

MultiCollinearity Statistics

\begin{tabular}{|l|c|c|}
\hline & Tolerance & VIF \\
\hline (Constant) & 0.474 & 2.109 \\
\hline Payment & .484 & 2.068 \\
\hline Benefit & .607 & 1.647 \\
\hline Promotion & .522 & 1.914 \\
\hline Working Condition & .703 & 1.422 \\
\hline Recognition & .803 & 1.245 \\
\hline Training & .569 & 1.758 \\
\hline
\end{tabular}

Source: own Survey 2019

A VIF of greater than 5 is generally considered the evidence of multicollinearity. However the VIF of every independent variable in the above collinearity statistics table is less than 5 . Thus, it can be concluded that all variables have low correlation power; as a result there is no multicollinearity problem among the independent variables.

\section{Linearity and Homoscedasticity test}

Multiple linear regression models assume there is a linear relationship between the independent variables and the dependent variables. And also Homoscedasticity assumption means the range of variance for the dependent variable is uniform for all values of the independent variables (Gujarati, 2004). Both assumptions can be checked by scatter plot diagram stated below.

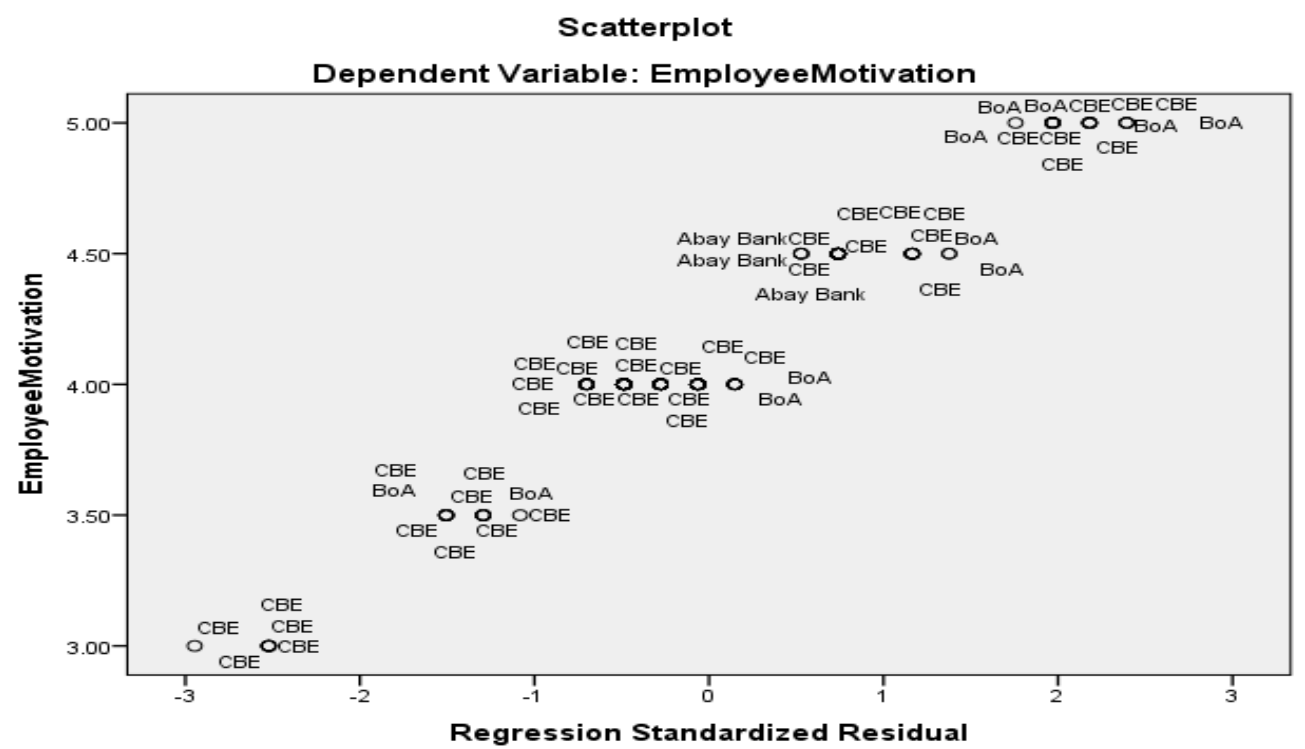

Scatter plot diagram for test of linearity

Source: own Survey 2019

The Scatter plot diagram shows the variance for the dependent variable is uniform and also the variance between the upper and lower cases of the observations are reasonably similar.

\section{Test of Independence of Residuals}

Multiple linear regression models assume the residuals are independent of one another. The Durbin-Watson statistic is used to test for the presence of serial correlation among the residuals. The value of the Durbin-Watson statistic ranges from 0 to 4 . As a general rule, the residuals are not correlated if the Durbin-Watson statistic is approximately 2 , and an acceptable range is $1.50-2.50$ (Gujarati, 2004). 


\section{Durbin-Watson}

\begin{tabular}{|l|r|r|r|r|r|}
\hline Model & R & R Square & $\begin{array}{c}\text { Adjusted R } \\
\text { Square }\end{array}$ & $\begin{array}{l}\text { Std. Error of } \\
\text { the Estimate }\end{array}$ & $\begin{array}{c}\text { Durbin- } \\
\text { Watson }\end{array}$ \\
\hline 1 & $.387^{\mathrm{a}}$ & .149 & .123 & .39062 & 2.142 \\
\hline
\end{tabular}

a. Predictors: (Constant), Training, WCondition, Payment, Benefit, Recognition, Promotion

b. Dependent Variable: Employees"e Motivation

Source; SPSS Results, 2019

\section{Regression Analysis}

Multiple regression analysis applied to find out whether there was statistically significant relation surfaced between work motivation and the six reward dimensions or not. Therefore, six extracted dimensions were taken as independent variables against motivation of employees as dependent variable in a $\mathrm{multiple}$ regression model. For all the hypothesis of the study $95 \%$ confidence interval is used.

\section{The effect of reward practices on employees' motivation}

To know about the effect of individual dimensions of reward variables on the employee's motivation Multiple regressions using the following model were employed:

$$
\boldsymbol{Y}=\alpha+\beta_{1} P+\beta_{2} B+\beta_{3} P r+\beta_{4} W+\beta_{5} R+\beta_{6} T+U i
$$

$$
\begin{aligned}
& \text { Motivation } \left.=\alpha+\beta_{1}(\text { Payment })+\beta 2(\text { Benefit })+\beta 3 \text { (Promotion }\right)+\beta 4(\text { Working condition })+ \\
& \beta_{5}(\text { Recognition })+\beta 6(\text { Training })+U i
\end{aligned}
$$

Model Summary in each bank

\begin{tabular}{|l|c|r|r|r|r|}
\hline Name of the bank & Model & R & R Square & $\begin{array}{c}\text { Adjusted R } \\
\text { Square }\end{array}$ & $\begin{array}{l}\text { Std. Error of the } \\
\text { Estimate }\end{array}$ \\
\hline CBE & 1 & $.554^{\mathrm{a}}$ & .307 & .269 & .38218 \\
\hline BoA & 1 & $.618^{\mathrm{b}}$ & .382 & .250 & .37989 \\
\hline Abay Bank & 1 & $.646^{\mathrm{c}}$ & .417 & .333 & .25532 \\
\hline
\end{tabular}

Source: own Survey 2019

ANOVA in each bank

\begin{tabular}{|lll|r|r|r|r|r|}
\hline $\begin{array}{l}\text { Name of } \\
\text { the bank }\end{array}$ & \multicolumn{2}{l|}{ Model } & & Df & Square & F & \\
\hline CBE & 1 & Regression & 7.051 & 6 & 1.175 & 8.046 & \\
& & Residual & 15.921 & 109 & .146 & & \\
& & Total & 22.972 & 115 & & & Sig. \\
\hline BoA & 1 & Regression & 2.502 & 6 & .417 & 2.889 & $.000^{\mathrm{a}}$ \\
& & Residual & 4.041 & 28 & .144 & & \\
& & Total & 6.543 & 34 & & & \\
\hline Abay & 1 & Regression & 1.956 & 6 & .326 & 5.001 & $.026^{\mathrm{b}}$ \\
Bank & & Residual & 2.738 & 42 & .065 & & \\
& & Total & 4.694 & 48 & & & \\
\hline
\end{tabular}

\section{Source: own Survey 2019}

ANOVA analysis is normally used to compare the mean scores of more than two groups or variables. It is also called analysis of variance because it compares the variance between groups (Pallant, 2005). The above ANOVA table 4.16 indicates the statistical significance of the regression model that is run. Here, $p$ is less than 0.05 , and indicates that, overall, the regression model statistically significantly predicts the outcome variable (i.e., it is a good fit for the data). 
The $\mathrm{F}$ ratio or $\mathrm{F}$ statistic represents the variance. If the $\mathrm{F}$ ratio is large and probability is less than 0.05 then it is termed statistically significant (Saunders, 2012). Accordingly, as can be seen from the table below the $\mathrm{F}$ value is 8.046, 2.889 and 5.001 and also is significant at $0.000,0.026$ and 0.001 in CBE, BoA and Abay Bank respectively, Hence, the researcher can suggest that, the regression model adopted in this study is considered significant.

The R (Coefficient of Correlation) which is simply measures the degree of (linear) association between the dependent variable and the independent variables jointly. It only measures degree of association or between the two variables (Gujarati, 2004). $\mathrm{R}$ value tells that the relationship between the independent variables as a whole (payment, benefits, promotion, working condition, recognition, training) and employees ${ }^{\text {ee }}$ motivation. $\mathrm{R}$ value $0.554,0.618$, and 0.646 for $\mathrm{CBE}$, BoA and Abay Bank respectively, means there is a moderate relationship between independent and dependent variables. R-square can be viewed as the proportion of the total variation or dispersion in the motivation (dependent variable) that explained by the variation in independent variables in the regression. The $\mathrm{R}$ square value $0.307,0.382$ and 0.417 for $\mathrm{CBE}, \mathrm{BoA}$ and $\mathrm{Abay}$ Bank respectively, indicates that in CBE $30.7 \%$ of variation on dependent variable (motivation) is explained by the above Reward dimensions (payment, benefits, promotion, working condition, recognition and training), and other factors that are not included in the model may explain the remaining $(69.93 \%)$ variation in employees ${ }^{\text {"e }}$ motivation. And in BoA R-square value 0.382 indicates that $38.2 \%$ of variation on dependent variable (motivation) is explained by the above reward dimensions (payment, benefits, and promotion, working condition recognition and training). And other factors that are not included in the model may explain the remaining $(61.8 \%)$ variation in employees" motivation. And finally in Abay Bank the value of $\mathrm{R}$ square $=0.417$ indicates that $41.7 \%$ of variation on dependent variable (motivation) is explained by the above reward dimensions (payment, benefits, promotion, working condition, recognition and training), and other factors that are not included in the model may explain the remaining $(58.3 \%)$ variation in employee's motivation. Coefficients of Regression Model in each bank

\begin{tabular}{|c|c|c|c|c|c|c|c|}
\hline \multirow{2}{*}{$\begin{array}{l}\text { Name of } \\
\text { the bank }\end{array}$} & \multirow{2}{*}{\multicolumn{2}{|c|}{ Model }} & \multicolumn{2}{|c|}{$\begin{array}{c}\text { Unstandardized } \\
\text { Coefficients }\end{array}$} & \multirow{2}{*}{$\begin{array}{c}\begin{array}{c}\text { Standardized } \\
\text { Coefficients }\end{array} \\
\text { Beta } \\
\end{array}$} & \multirow[b]{2}{*}{$\mathbf{T}$} & \multirow[b]{2}{*}{ Sig. } \\
\hline & & & B & Std. Error & & & \\
\hline \multirow[t]{7}{*}{ CBE } & 1 & (Constant) & 3.676 & .219 & & 16.764 & .000 \\
\hline & & Payment & .108 & .057 & .217 & 1.889 & .062 \\
\hline & & Benefit & .035 & .050 & .071 & .693 & .490 \\
\hline & & Promotion & -.210 & .055 & -.424 & -3.845 & .000 \\
\hline & & $\begin{array}{l}\text { Working } \\
\text { Condition }\end{array}$ & -.099 & .044 & -.215 & -2.261 & .026 \\
\hline & & Recognition & .144 & .041 & .313 & 3.518 & .001 \\
\hline & & Training & .143 & .047 & .319 & 3.016 & .003 \\
\hline \multirow{8}{*}{ BoA } & \multirow{8}{*}{1} & (Constant) & 3.868 & .647 & & 5.979 & .000 \\
\hline & & Payment & .256 & .088 & .581 & 2.918 & .007 \\
\hline & & Benefit & .080 & .085 & .179 & .942 & .354 \\
\hline & & Promotion & .055 & .098 & .144 & .563 & .578 \\
\hline & & Working & .246 & .179 & .332 & 1.376 & .180 \\
\hline & & & -.193 & .112 & -.450 & 1.. & 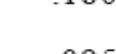 \\
\hline & & Recognition & 158 & 088 & & -1.728 & .095 \\
\hline & & Training & & & & 1.799 & .083 \\
\hline \multirow{8}{*}{$\begin{array}{l}\text { Abay } \\
\text { Bank }\end{array}$} & \multirow{8}{*}{1} & (Constant) & 139 & 4 & & 7.098 & .000 \\
\hline & & Payment & 139 & .124 & .207 & 1.122 & .268 \\
\hline & & Benefit & .240 & .082 & .717 & 2.920 & .006 \\
\hline & & Promotion & & .058 & .342 & 1.860 & .070 \\
\hline & & Working &. .132 & .058 & -.327 & -2.274 & .028 \\
\hline & & Condition & .117 & .146 & & & \\
\hline & & Recognition & .245 & .105 & .229 & -806 & .425 \\
\hline & & Training & & & .471 & 2.332 & .025 \\
\hline
\end{tabular}

a) Predictors, (constant), payment, benefits, promotion, working condition, recognition, and training

The regression coefficients explain the average amount of change in the dependent variable due to a unit 
change in the independent variable holding other explanatory variables constant.

Regression analysis between Private Banks and CBE

Model Summary

\begin{tabular}{|l|l|r|r|r|r|}
\hline Bank & Model & R & R Square & \multicolumn{1}{c|}{$\begin{array}{c}\text { Square } \\
\text { Estimate }\end{array}$} \\
\hline Private & 1 & $.461^{\mathrm{a}}$ & .212 & .151 & .33919 \\
\hline bank & 1 & $.554^{\mathrm{a}}$ & .307 & .269 & \\
\hline
\end{tabular}

a. Predictors: (Constant), Training, Working Condition, Benefit,

Payment, Promotion, Recognition

\begin{tabular}{|c|c|c|c|c|c|c|c|}
\hline \multirow[b]{2}{*}{ Bank } & & & \multicolumn{2}{|c|}{$\begin{array}{c}\text { Unstandardized } \\
\text { Coefficients }\end{array}$} & \multirow{2}{*}{\begin{tabular}{|c|}
$\begin{array}{c}\text { Standardized } \\
\text { Coefficients }\end{array}$ \\
Beta
\end{tabular}} & \multirow[b]{2}{*}{$t$} & \multirow[b]{2}{*}{ Sig. } \\
\hline & \multicolumn{2}{|c|}{ Model } & B & Std. Error & & & \\
\hline \multirow{8}{*}{ Private bank } & 1 & (Constant) & 4.504 & .277 & & 16.239 & .000 \\
\hline & & Payment & .186 & .064 & .389 & 2.916 & .005 \\
\hline & & Benefit & .038 & .055 & .103 & .681 & .498 \\
\hline & & Promotion & .093 & .055 & .298 & 1.711 & .091 \\
\hline & & Working & & & & & \\
\hline & & Condition & .029 & .056 & .059 & .520 & .605 \\
\hline & & Recognition & -.214 & .083 & -.527 & -2.569 & .012 \\
\hline & & Training & .190 & .053 & .589 & 3.592 & .001 \\
\hline \multirow{7}{*}{$\mathrm{CBE}$} & & (Constant) & 3.676 & .219 & & 16.764 & .000 \\
\hline & 1 & Payment & .108 & .057 & .217 & 1.889 & .062 \\
\hline & & Benefit & .035 & .050 & .071 & .693 & .490 \\
\hline & & Promotion & -.210 & .055 & -.424 & -3.845 & .000 \\
\hline & & W/Condition & -.099 & .044 & -.215 & -2.261 & .026 \\
\hline & & Recognition & .144 & .041 & .313 & 3.518 & .001 \\
\hline & & Training & .143 & .047 & .319 & 3.016 & .003 \\
\hline
\end{tabular}

a. Dependent Variable: employee's Motivation

From the above table the $\mathrm{R}$ value 0.554 , and 0.461 for $\mathrm{CBE}$ and private banks respectively, means there is a moderate relationship between independent and dependent variables. Whereas the R-square value 0.307 and 0.212 in CBE and Private Banks respectively, indicates that in CBE $30.7 \%$ of variation on dependent variable (motivation) is explained by the above Reward dimensions (payment, benefits, promotion, working condition, recognition and training), and other factors that are not included in the model may explain the remaining $(69.93 \%)$ variation in employee's motivation. However in private banks $21.2 \%$ of variation on 
dependent variable (motivation) is explained by the above Reward dimensions and other factors that are not included in the model may explain the remaining (78.8\%) variation in employee's motivation.

\section{Testing hypothesis}

Based on the above regression result of $\mathrm{CBE}$ and Private Banks, the hypothesis of the study are tested and presented as follows

\section{Payment}

H1: payment has a positive and significant effect on employee's motivation.

As we can see in the above regression coefficient table payment has a beta value $.108, \mathrm{p}$ value .062 in CBE and in Private Banks beta value .186, $\mathrm{p}$ value .005, according to the result we found that payment is significant for Private Banks, however, it is insignificant for CBE this may be due to the problem of payment system in CBE. But Payment can be significant for CBE at margin error of $10 \%(90 \%$ confidence interval). This result of payment is consistent with Moncarz et al., (2009). According to his paper it can be explained that salary was the prime factor for the motivation of salaried employees.

\section{Benefit}

$\mathrm{H} 2$ : benefit has a positive and significant effect on employee's motivation.

The beta value of benefit shows $.035, \mathrm{p}$ value .490 in CBE and beta value $.038, \mathrm{p}$ value .498 in private banks, which tells us benefit has no significant effect on employee's motivation. Therefore we reject the alternate hypothesis. This result could be supported by Herzberg two factors theory. He states that In fact, the basic benefits such as facilities like adequate working space do not necessarily ensure that employees are happy and motivated.

\section{Working condition}

H1: Working condition has a positive and significant effect on employee's motivation.

Working condition also found to be insignificant influence on motivation in CBE and Private Banks.

Therefore we accept the null hypothesis and reject the alternate one. This insignificant coefficient of working condition is consistent with Robbins (2001). According to his papers absence of working conditions such as good temperature, lighting, ventilation, hygiene, noise, working hours, staff relation and resources can impacts poorly on the worker's mental and physical well-being.

\section{Promotion}

H1: Employees promotion has a positive and significant effect on employee's motivation.

The regression result in $\mathrm{CBE}$ about the promotion is insignificant. However promotion is significant in private banks at $90 \%$ confidence level, the result shows promotion is properly done in private banks than CBE. This finding can be supported by (De Souza, 2002) which states that If organizations are not giving promotion to their employees then employees will be de-motivated and their turnover rate will be high.

\section{Recognition}

H1: employee's recognition has a positive and significant effect on employee's motivation.

In CBE Statistically significant and positive relationships was also absorbed between recognition and employee's motivation but in private banks recognition is found insignificant for employee's motivation. Therefore, the hypothesis is accepted in CBE and rejected in Private Banks. This insignificancy of recognition on employee's motivation may be the indication of private banks did not recognized top achiever employees.

\section{Training}

H1: Training has a positive and significant effect on employee's motivation.

Training has significant effect on employee's motivation with $\mathrm{p}$ value of .003 and .001 in CBE and Private Banks respectively.. Therefore we reject the null hypothesis and accept the alternate hypothesis. This result is also consistent with (Zafar, 2014) according to his finding, training has a positive significant effect on employees ${ }^{\text {ee }}$ motivation. Based on the above analysis the researcher concludes that payment and training variables are significant on employee's motivation in private banks, where as in CBE recognition and training have a positive effect and significant with employee's motivation, and the rest variables are found insignificant for both banks. 


\section{CONCLUSION AND RECOMMENDATIONS \\ Conclusion}

The main objective of this research was to assess the effect of reward practices on employee's motivation in the case of CBE and Private Banks (BoA and Abay bank) in South Gondar Zone. As stated in the literature the six explanatory variables of motivation are; payment, benefits, promotion, working condition, recognition and training opportunity.

$>$ The result of descriptive analysis shows that all explanatory variables except payment and promotion have the mean value of above the average in CBE. This implies that employees attitude towards the reward programs given by the bank is high. In addition to this mean value of motivation shows that the level of motivation in $\mathrm{CBE}$ is also high.

$>$ Descriptive analysis also shows that all explanatory variables except training and promotion have the mean value of above the mid-scale in BoA. And also all explanatory variables have the mean value of above the mid-scale in Abay bank. This implies that employees" attitude towards the reward programs given by the private banks (BoA and Abay bank) is relatively high than CBE. In addition to this mean value of motivation shows that the level of employees ${ }^{\text {ee }}$ motivation in BoA and Abay bank was better than CBE.

$>$ The correlation between motivation and reward dimensions presented in the analysis, we can conclude that reward such as payment, promotion, benefit; recognition and training opportunity have positive relationship with employee's motivation in $\mathrm{CBE}$ and Private Banks, However working condition has not positively correlated with employee's motivation in both banks.

$>$ From the regression result we can conclude that recognition, training and also Payment for $(\mathrm{p}<0.1)$ have positive and significant effect on motivation but rewards such as, promotion, working condition and benefit do not have significant effect on employee's motivation in CBE, Where as in Private Banks training opportunity as well as payment has a positive and significant effect on employee's motivation but the other reward dimension in the model are found insignificant.

\section{Recommendations}

Based on the findings and conclusions of the research the following recommendations are forwarded.

$>$ Since recognition has higher positive and significant impact on employees ee motivation in CBE, but this variable is found insignificant for private banks, which implies that recognition practice is poor in private banks. Therefore we recommend that supervisors and managers have to acknowledge employees deeds on a daily/weekly/monthly basis and implementing a formal program to recognize top achievers in every job category is important.

$>$ In CBE payment and promotion variables are found insignificant on employee's motivation, but they are significant in private banks. These indicate that the promotion and payment system is not good in CBE. Then we recommend that since the current market is full of competition the bank should improve the payment system and the promotion practices for motivating and retention of employees. And also we recommend that both banks should go along with those significant variables for better motivation of employees.

$>$ The study also recommends that future research be directed towards investigating how other reward variables like employees" autonomy, responsibility, work content, leadership influence employee's motivation. And other unaddressed non reward variables that influence employee's motivation, since motivation of employees could be affected by many factors other than rewards.

\section{References}

Abdul H., 2014, Impact of Compensation on Employee Performance (Empirical Evidence from Banking Sector of Pakistan), International Journal of Business and Social Science Vol. 5 No. 2; February 2014

Ali, R. and Ahmed, M. S. (2011). The impact of reward and recognition programs on employee's motivation and satisfaction: an empirical study. International Review of Business Research papers, Vol. 5 No. 4

Armstrong and Murlis. (2004). human resource management, 3rd edition.

Armstrong. (2005). Employee Reward Management and Practice.London: Kogan page Limited.

Armstrong. (2009). Armstrong's handbook of performance management,4th edition London and Philadelphia kogan page Ltd.

Bowley. (1926). Sample size determination technique; university of mathematics association; vol.12.

Cerri. (2012). "Exploring the Relationships among Service Quality, Satisfaction, Trust and Store Loyalty among Retail Customers,. Journal of Competitiveness." Vol. 4, Issue 4, pp. 16-35.

Malik, M.Muhammed, S.and Malira,M.(2011). (2011). Association between reward and employee motivation.Vol,5no,1.

Mohemmed, M. (2011). determinants of employees engagement in kenya NGOs, unpublished thesis, Nairobi. 
Nida Z. et al. (2014). Determinants of employee motivation and its impact on knowledge transfer and jobsatisfaction. International journal of human resource studies .

Torrington, D., Hall, L., \& Taylor, S. (2009). Human Resource Management, 7th edn.

U.S., M. (2013). The Impact of Employee Motivation On Organisational Performance. The International JournalOf Engineering And Science (IJES) .

Yamane. (1967). population and sample size determination.

Zafar, N. (2014). Determinants of Employee Motivation and its impact on Knowledge Transfer and Job Satisfaction. International Journal of Human Resource Studies. 